\title{
DETECTION OF SOME PATHOGENIC BACTERIA IN CHICKEN MEAT SOLD IN POULTRY SHOPS
}

\author{
SHEREEN A. YASSIN and GHADA A. EL-GAMMAL \\ Department of Food Hygiene and Bacteriology, Animal Health Research Institute, Kafrelshiekh Branch, Egypt.
}

Received: 24 August 2016; Accepted: 26 September 2016

\begin{abstract}
The current study was done to evaluate the microbiological status of some of the retailed chicken meat. A total of 50 random samples of chicken meat were collected from different poultry shops at Kafrelshiekh Governorate. The samples were evaluated bacteriologically for the detection of some food poisoning pathogens (Salmonella, E.coli and Staphylococcus aureus). The obtained results revealed that Salmonella spp. were isolated with a percentage of $18 \%$, furthermore, the serological identification of the obtained isolates revealed the presence of $S$. Typhimurium (6\%), S. Enteritidis (4\%), S. Kentucky (4\%), S. Molade (2\%) and $S$. Infants (2\%). On the other hand, E.coli was detected in $12 \%$ of the examined sample, and the serological identification of the obtained isolates revealed the presence of the following serotypes $\mathrm{O}_{78}, \mathrm{O}_{103}: \mathrm{H}_{2}, \mathrm{O}_{1}: \mathrm{H}_{7}$ and $\mathrm{O}_{125}: \mathrm{H}_{21}$. About $20 \%(10$ isolates) of the examined samples were belonging to Staph. aureus. Detection of Staph. aureus enterotoxin by using multiplex PCR indicates that only 4 strains from the 10 isolates were positive for enterotoxin production One isolate produce Sea, Sec; One isolate produce Sea; one isolate Sec; and the last isolate produce Sea, Seb, Sed enterotoxin. Based on the obtained results, it was concluded that chicken meat poses high risk for public heath, so strict hygienic measures should be taken during slaughtering and processing to prevent cross contamination.
\end{abstract}

Key words: Chicken meat, Salmonellae, E.coli, Staphylococcus aureus, Staphylococal enterotoxins

\section{INTRODUCTION}

Meat of chicken broilers are more popular to the consumers because of its easy digestibility and acceptance by the majority of people, although it could be contaminated with a variety of potentially pathogenic food borne pathogens that may cause human illness such as Salmonella, staph. aureus, and E.coli (Mulder and Schlundt, 1999).

Outbreaks of food borne illness occur following ingestion of undercooked meat, handling of raw meat, cross contamination of ready-to-eat products with microbial contaminants from the raw poultry or others introduced during preparation of food (Anon, 1996). Poultry and poultry products are frequently contaminated with salmonellae that can be transmitted to humans either through the handling of raw poultry carcasses and products (Kimura et al., 2004). Because salmonella typically is found in poultry, this type of meat has been an important vehicle in food borne diseases rendering salmonellosis as one of the most frequently reported food borne diseases worldwide (WHO/FAO, 2002).

Corresponding author: Dr. SHEREEN A. YASSIN

E-mail address: shereen_color@yahoo.com

Present address: Department of Food Hygiene and Bacteriology, Animal Health Research Institute, Kafrelshiekh Branch, Egypt.
Escherichia coli is a major component of the normal intestinal flora of humans and other mammals. Some E.coli strains represent primary pathogens with an enhanced potential to cause disease after acquiring specific virulence attributes. These virulence attributes are normally encoded on genetic elements that can be exchanged between different strains, the presence of these virulence genes can magnitude the severity of infection caused by these strains ( $\mathrm{Li}$ et al., 2005).

Escherichia coli is known to be an indicator of fecal contamination, and its presence in food indicates the possible presence of other enteric pathogen. Some of the E.coli strains itself are highly pathogenic in human and animal. People with low immunity are the prime target of the pathogenic strains of E.coli (Akbar and Anal, 2011).

Staphylococcus aureus is one of the most important amongst staphylococci species, it is considered the third worldwide cause amongst the food-borne illnesses reported cases (Tamarapu et al., 2001).

In human this bacterium is a major cause of food poisoning, pneumonia, postoperative wound infections, and nosocomial bacteremia, (Sidhu et al., 2007). Staphylococcal enterotoxins are resistant to environmental conditions (freezing, drying, heat 
treatment and low $\mathrm{pH}$ ) that easily destroy the enterotoxin-producing strain. They are also resistant to proteolytic enzymes retaining their activity in the digestive tract after ingestion (Bergdoll, 1989).

Therefore, the present study was planned out to throw the light on some pathogenic bacteria as Salmonellae, E. coli and Staph. aureus isolated from chicken meat and their public health importance.

\section{MATERIALS AND METHODS}

Collection of samples:

A total of 50 samples of deboned poultry meat $(25$ chicken breast and 25 chicken thigh) were randomly collected from different retail poultry shops at Kafrelsheikh Governorate. The samples were transferred aseptically with minimum of delay to the laboratory in an insulating container where about 10 grams of chicken meat were transferred to $90 \mathrm{ml}$ of $0.1 \%$ sterile buffered peptone water then stomached for $2 \mathrm{~min}$. the homogenate then used for bacteriological examination.

\section{Isolation and identification of Salmonellae:}

The procedures for isolation of Salmonellae according to the techniques recommended by ISO 6579 (2002), morphological and biochemical identification were carried out according to Cruickshank et al. (1975). Serological identification of salmonellae isolates was carried out according to (Kauffman, 1974) for the determination of Somatic (O) and Flagellar $(\mathrm{H})$ antigens using Salmonellae antiserum (DENKA SEIKEN Co., Japan). In the food analysis center, faculty of veterinary medicine Benha University.

\section{Isolation and identification $E$. coli:}

Isolation of $E$. coli was done according to (Feng et al., 2002). Further biochemical assays, as per Bergey's manual of determinative bacteriology (Holt et al., 1994). The serological identification of isolates was carried out according to Kok et al. (1996) by using rapid diagnostic E. coli antisera kits (Denka Seiken Co., Japan) for diagnosis of the Enteropathogenic types.

\section{Isolation and identification of Staph. aureus:}

It was carried out according to per Bergey's manual of determinative bacteriology (Holt et al., 1994). Screening for pathogenic Staph. aureus was done by performing various biochemical assays, including Coagulase test, DNase test (Baird, 1996), and Thermostable nuclease test (TNase) (Lachica et al., 1971).

4. Multiplex PCR for demonstration of staphylococcus enterotoxins genes:-

4.1. Primer sequences of Staph. aureus used for PCR identification system:

Application of PCR for demonstration of enterotoxins A, B, C and D (sea, seb, sec \&sed) genes as virulence factors of Staph. aureus was performed essentially by using primers (Pharmacia Biotech) as shown in the following table:

Table 1: Target genes used in multiplex PCR assay:

\begin{tabular}{|c|c|c|c|}
\hline Target gene & Oligonucleotide sequence $\left(5^{\prime} \rightarrow 3^{\prime}\right)$ & $\begin{array}{l}\text { Product size } \\
\text { (bp) }\end{array}$ & References \\
\hline Sea $(F)$ & $\mathbf{5}^{\prime}$ TTGGAAACGGTTAAAACGAA'3 & \multirow[b]{2}{*}{120} & \multirow{8}{*}{ Rall et al. (2008) } \\
\hline Sea $(\mathrm{R})$ & 5' GAACCTTCCCATCAAAAACA '3 & & \\
\hline $\operatorname{Seb}(F)$ & $\mathbf{5}^{\prime}$ TCGCATCAAACTGACAAACG ' 3 & \multirow{2}{*}{478} & \\
\hline $\operatorname{Seb}(\mathrm{R})$ & 5' GCGGTACTCTATAAGTGCC '3 & & \\
\hline $\operatorname{Sec}(F)$ & $\mathbf{5}^{\prime}$ GACATAAAAGCTAGGAATTT '3 & \multirow[b]{2}{*}{257} & \\
\hline $\operatorname{Sec}(\mathrm{R})$ & 5' AAATCGGATTAACATTATCC '3 & & \\
\hline Sed $(F)$ & 5' CTAGTTTGGTAATATCTCCT '3 & \multirow[b]{2}{*}{317} & \\
\hline Sed $(\mathrm{R})$ & $\mathbf{5}^{\prime}$ TAATGCTATATCTTATAGGG ' 3 & & \\
\hline
\end{tabular}

\subsection{DNA Extraction using QIA amp kit (Shah et al., 2009):}

After overnight culture on nutrient agar plates, one or two colonies were suspended in $20 \mathrm{ml}$ of sterile distilled water, then heated at $100^{\circ} \mathrm{C}$ for 20 minutes. Accurately, 50-200 $\mu 1$ of the culture were placed in
Eppendorf tube and then equal volume from the lysate $(50-200 \mu \mathrm{l})$ was added, addition of $20-50 \mu 1$ of proteinase $\mathrm{K}$, then incubation at $56^{\circ} \mathrm{C}$ for $20-30 \mathrm{~min}$. After incubation, $200 \mu \mathrm{l}$ of $100 \%$ ethanol was added to the lysate. The solution was added to the column and centrifuged at $8000 \mathrm{rpm}$ for $1 \mathrm{~min}$. then the 
filtrate was discarded. The sediment was washed using AW1 buffer $(200 \mu \mathrm{l})$, the column was centrifuged at $8000 \mathrm{rpm} / 1 \mathrm{~min}$, and the filtrate was discarded. Washing was applied by using the AW2 buffer $(200 \mu \mathrm{l})$, the column was centrifuged at 8000 $\mathrm{rpm} / 1 \mathrm{~min}$. and the filtrate was discarded. The column was placed in a new clean tube then, 25-50 $\mu 1$ from the Elution buffer was added, centrifuged at $8000 \mathrm{rpm} / 1 \mathrm{~min}$. Then the column was discarded. The filtrate was put in clean tube containing the pure genomic DNA. Nucleic acid was eluted with $100 \mu \mathrm{l}$ of elution buffer provided in the kit.

4.3. Amplification of enterotoxin genes of Staph. aureus (Mehrotra et al., 2000):

The amplification was performed on a Thermal Cycler (Master cycler, Eppendorf, Hamburg,
Germany). DNA amplification was performed using the following conditions: initial denaturation for 5 min at $95^{\circ} \mathrm{C}$ followed by 30 cycles of denaturation $\left(94^{\circ} \mathrm{C}\right.$ for $\left.2 \mathrm{~min}\right)$, annealing $\left(55^{\circ} \mathrm{C}\right.$ for $\left.1 \mathrm{~min}\right)$, and extension $\left(72^{\circ} \mathrm{C}\right.$ for $\left.2 \mathrm{~min}\right)$. A final extension step $\left(72{ }^{\circ} \mathrm{C}\right.$ for $5 \mathrm{~min}$ ) was done after the completion of the cycles.

Amplified products were analyzed by $3 \%$ of agarose gel electrophoresis (Applichem, Germany, $\mathrm{GmbH}$ ) in $1 \mathrm{x}$ TBE buffer stained with ethidium bromide and captured as well as visualized on UV transilluminator at $254 \mathrm{~nm}$. A 100 bp plus DNA Ladder (Qiagen, Germany, GmbH) was used to determine the fragment sizes.

\section{RESULTS}

Table 2: Incidence of bacteria isolated from examined chicken meat samples.

\begin{tabular}{|c|c|c|c|c|c|c|c|}
\hline \multirow{2}{*}{ Type of the samples } & \multirow[t]{2}{*}{ No of the samples } & \multicolumn{2}{|c|}{ Salmonella } & \multicolumn{2}{|c|}{ E. coli } & \multicolumn{2}{|c|}{ Staph. aureus } \\
\hline & & No & $\%$ & No & $\%$ & No & $\%$ \\
\hline Chicken breast & 25 & 3 & 12 & 0 & 0 & 7 & 28 \\
\hline Chicken thigh & 25 & 6 & 24 & 6 & 24 & 3 & 12 \\
\hline Total & 50 & 9 & 18 & 6 & 12 & 10 & 20 \\
\hline
\end{tabular}

Table 3: Incidence and serotypes of Salmonellae isolated from examined chicken meat samples. (no. $=50)$

\begin{tabular}{|c|c|c|c|c|c|c|}
\hline \multirow{2}{*}{$\begin{array}{l}\text { No. of total } \\
\text { positive } \\
\text { samples }\end{array}$} & \multirow[t]{2}{*}{ Percentage \% } & \multirow{2}{*}{$\begin{array}{l}\text { Identified } \\
\text { serotypes }\end{array}$} & \multirow{2}{*}{$\begin{array}{c}\text { No. of } \\
\text { isolates }\end{array}$} & \multirow[t]{2}{*}{ Percentage $\%$} & \multicolumn{2}{|c|}{ Antigenic structure } \\
\hline & & & & & $\mathbf{O}$ & $\mathbf{H}$ \\
\hline \multirow{5}{*}{9} & \multirow{5}{*}{$18 \%$} & S.Typhmurium & 3 & $6 \%$ & $\mathrm{i}=1,2$ & $1,4,5,12$ \\
\hline & & S. Enteritidis & 2 & $4 \%$ & $\mathrm{~g}, \mathrm{~m}: 1,7$ & $1,9,12$ \\
\hline & & S. Kentucky & 2 & $4 \%$ & $\mathrm{i}: \mathrm{Z}_{6}$ & 8,20 \\
\hline & & S. Molade & 1 & $2 \%$ & $\mathrm{Z}_{10}: \mathrm{Z}_{6}$ & 8,20 \\
\hline & & $S$. Infantis & 1 & $2 \%$ & $\mathrm{r}: 1.5$ & 6,7 \\
\hline
\end{tabular}


Table 4: Incidence and serotypes of E.coli isolated from examined chicken meat samples. (no. =50)

\begin{tabular}{cccccc}
\hline $\begin{array}{l}\text { No. of total } \\
\text { positive samples }\end{array}$ & Percentage\% & E. coli serotype & No. of isolates & $\%$ & Strain characterization \\
\hline & \multirow{2}{*}{$12 \%$} & $\mathrm{O}_{\mathbf{7 8}}$ & 3 & 6 & EPEC $^{*}$ \\
\cline { 2 - 5 } 6 & $\mathrm{O}_{\mathbf{1 0 3}}: \mathrm{H}_{\mathbf{2}}$ & 1 & 2 & $\mathrm{EHEC}^{*}$ \\
\cline { 2 - 5 } & & $\mathrm{O}_{\mathbf{1}}: \mathrm{H}_{\mathbf{7}}$ & 1 & 2 & $\mathrm{EPEC}^{*}$ \\
\hline & $\mathrm{O}_{\mathbf{1 2 5}}: \mathrm{H}_{\mathbf{2 1}}$ & 1 & 2 & $\mathrm{ETEC}^{*}$ \\
\hline & & & & \\
& & 6 & $12 \%$ & \\
\hline
\end{tabular}

$\operatorname{EPEC}^{*}$ (enteropathogenic E.coli).

EHEC $^{*}$ (enteroheamorrgic E.coli).

ETEC $^{*}$ (enterotoxogenic E. coli).

Table 5: Incidence of Staph. aureus from examined chicken meat samples. (no.=50)
No. of isolates
$\%$

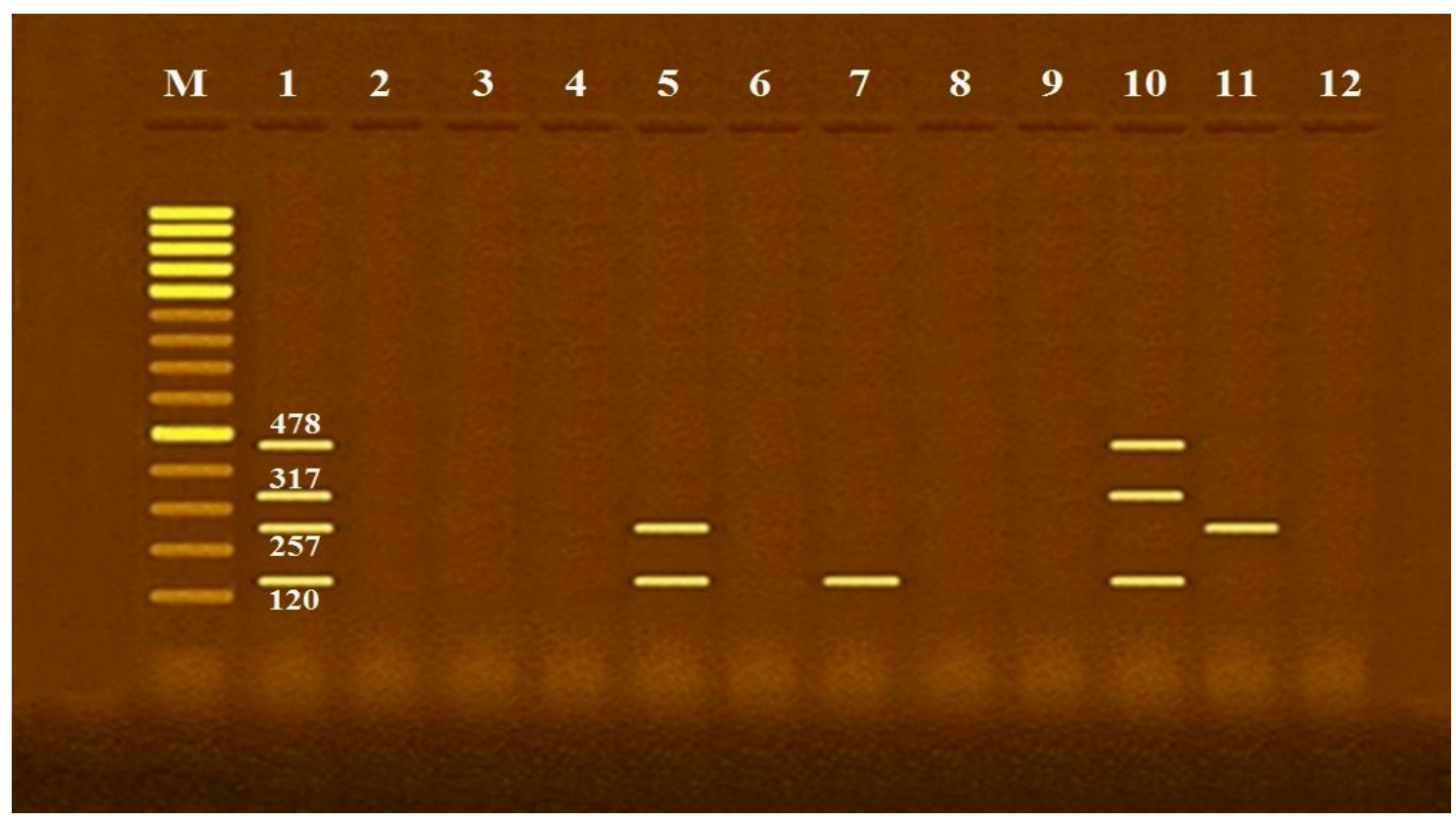

Photograph 1: Agarose gel electrophoresis of multiplex PCR of sea (120 bp), seb (478 bp), sec (257 bp) and sed (317 bp) enterotoxin genes for characterization of S. aureus.

Lane M: 100 bp ladder as molecular size DNA marker.

Lane 1: Control positive for sea, seb, sec and sed genes.

Lane 2: Control negative.

Lane 5: Positive $S$. aureus strain for sea and sec genes.

Lane 7: Positive $S$. aureus strain for sea gene.

Lane 10: Positive $S$. aureus strain for sea, seb and sed genes.

Lane 11: Positive $S$. aureus strain for sec gene.

Lanes 3, 4, 6, 8, 9 \& 12: Negative $S$. aureus strains for enterotoxins 


\section{DISCUSSION}

Although chicken meat is rightly regarded as a wholesome nutritious and cheap form of dietary protein, it is associated with some of food-borne illness due to microbial contamination and improper handling. Mass production of chicken meat and its rapid distribution pose a particular risk for wide spread food-borne outbreak infection with enteropathogens (Letellier, 1999).

The muscle tissue and body fluids of healthy living birds are usually free from bacteria, but during slaughtering and processing contamination occurs and cannot be avoided leading to introduction of pathogens into the meat. The source of these pathogens may be endogenous from the gastrointestinal tract or from surrounding environment in farm or slaughterhouse. Poultry are the most common food vehicle of human infection with enteropathogens throughout the world (Abd ElAziz et al., 2001).

Salmonellae, a genus within Enterobacteriaceae remains as an important human pathogen and it has been reported to be the most common foodborne bacterial disease in the world (Coburn et al., 2007).

Poultry is one of the most important reservoirs of Salmonellae that can be transmitted to humans through the dealing with chicken meat and/or consumption of uncooked meat and eggs (Wales and Davies, 2011; Nawar and Khedr 2014).

In the present study, incidence of Salmonellae as shown in Table (3) revealed the isolation of 9 Salmonellae strains with a percentage of (18\%); including $3(6 \%) S$. Typhimurium and 2(4\%) for each of $S$. Enteritidis and S.Kentucky, and $1(2 \%)$ for each of $S$. Molade and $S$. Infantis. Nearly similar percentage of isolation were recorded by Geilhausen et al. (1996), Uyttendaele et al. (1998) and Salehi et al. (2005) who isolated Salmonellae at percentage of $20 \%, 19 \%$ and $16 \%$, respectively.

Higher results were shown by Change (2000), Whyte et al. (2002), Zhao et al. (2006) and Mohammed (2012) who isolated Salmonellae at percentage of $25.9 \%, 23 \%, 39 \%$ and $56 \%$ respectively. While on the other hand lower results were shown by Jamshidi et al. (2009), Rabie et al. (2012) and Amin and Abd el- Rahman (2015) who isolated Salmonellae at percentage of $8.3 \%, 4 \%$ and $3.5 \%$ respectively.

The isolated Salmonellae in chicken meat may be attributed to contamination during slaughtering and/or processing which nearly similar to results achieved by Carraminana et al. (1997) who reported that the prevalence of Salmonellae in environmental samples ranged from $30 \%$ in faeces to $75 \%$ in scale water samples. The incidence rate for Salmonellae organisms on carcasses at the post-spray wash site.

It is noticed that, $S$.Typhimurium was the most prevalent isolated Salmonellae serotypes from broiler carcasses and many authors also recorded the isolation of $S$. Typhimurium from poultry meat as Moury et al. (1998), Tibaijuka et al. (2003), Hosam (2005), Amin and Abd el- Rahman (2015) who mentioned that $S$. Typhimurium was the predominant serotypes recovered from poultry meat.

The antigenic structure of isolated Salmonellae from broiler carcasses was: $S$. Enteritidis, 1, 9, 12 (O.strain), g, m: 1, 7 (H.strain);S. Typhmurium, 1, 4, 5, 12 (O.strain), $\mathrm{i}=1,2$ (H.strain); S. Infantis, 6, 7(O.strain), $\mathrm{r}: 1.5$ (H.strain); S. Molade, 8, 20 (O.strain), $\mathrm{Z}_{10}: \mathrm{Z}_{6}$ (H.strain); S. Kentucky 8, 20 (O.strain), i: $\mathrm{Z}_{6}$ (H.strain).

E. coli predominate among aerobic commensal flora present in the gut of man, animal and poultry. So, their presence in meat and poultry meat is indicative of faecal contamination and reflects the influence of handling practices of these products including preparation and faulty dealing by hands (Echeverria et al., 1987).

In many raw foods of animal origin, small number of $E$. coli can be expected because of the close association of these foods with animal environment and the likelihood of contamination of poultry carcasses from fecal material during processing (National Academy of science, 1985).

Data from this work revealed that E. coli strains were isolated from broiler carcasses at a percentage of $12 \%$ as shown in Table (4), nearly similar results were obtained by Wehab and Aideia (2002) and Vaidya et al. (2005) who isolated E. coli at percentage of $10 \%$ and $14.57 \%$ respectively. Higher percentages of isolation were reported by Bhattacharjee et al. (1996), Zhao et al. (2001), Hossain et al. (2008) who isolated E. coli at rates of $40.82 \%, 38.7 \%, \%$ and $63.6 \%$ respectively. Lower percentages of isolation were reported by Suthienkul et al. (1990) and Hossam (2012) who isolated E. coli at rates of $9 \%$, and $8 \%$, respectively.

Generally, the presence of $E$. coli in examined chicken meat is considered as an indicator for improper handling or unhygienic conditions (Frazier and Westhoff, 1983 and Hashim, 2003).

Out of the 6 strain isolated from chicken meat and the serovars were: $\mathrm{O}_{78}, \mathrm{O}_{1}: \mathrm{H}_{7}$ These isolated serovars belonged to enteropathogenic E.coli (EPEC); $\mathrm{O}_{103}: \mathrm{H}_{2}$ belonged to enteroheamorrgic E.coli (EHEC); $\mathrm{O}_{125}: \mathrm{H}_{21}$ belonged to enterotoxogenic $E$. coli (ETEC). 
Presence of pathogenic strains of E. coli in poultry meat is not only a potential threat of cross contamination but can also lead to become an infectious dose for handlers and consumers. E. coli presence in food materials are considered to be an indicator for the presence of other pathogenic bacteria in the respective food items (Shar et al., 2010).

Staph.aureus is the most concern to food microbiologists. Staphylococcal food poisoning is a syndrome characterized by nausea, vomiting, diarrhea, general malaise and weakness beginning one to six hours (usually 2 to 4 hrs.) after ingestion although the illness is seldom fatal and the complications including dehydration shock and may be accompanied with severe attacks. Recovery usually occurs after about 24 hours but may take several days (Eley, 1992 and Ward et al., 1997).

Results in Table (5) revealed that the incidence of staph.aureus was $20 \%$ in examined Broiler carcasses. Nearly similar results were detected by Momtaz et al. (2013) who isolated staph.aureus at a rate of $22.77 \%$ higher incidence were obtained by Kozacinski et al. (2006), Amin (2008), and Mohamed (2013) by incidence of $30.03 \%, 37 \%$, and $32 \%$ respectively.

Staphylococcal food poisoning (SFP) is one of the most common food-borne diseases and results from the ingestion of staphylococcal enterotoxins (SEs) preformed in food by enterotoxigenic strains of Staph. aureus more than 20 SEs have been described from SEA to SEIV. All of them have super antigenic activity whereas half of them have been proved to be emetic, representing a potential hazard for consumers Hennekinne et al. (2012).

The five major serological groups of enterotoxins (SEA, SEB, SEC, SED, and SEE) have been proven to induce gastro-enteric syndrome Klotz et al. (2003).

As shown in photopgraph (1), only four strains from the positive 10 strains of Staph.aureus were positive for enterotoxins detection and SEA was superior to other toxic genes as it detected in 3 isolates. One isolate produce $\mathrm{Sea}, \mathrm{Sec}$; One isolate produce Sea; one isolate Sec; and one isolate Sea, Seb, Sed enterotoxin.

Multiplex PCR technique has been recently used for rapid detection and discrimination of enterotoxins genes. Regarding the enterotoxin genotype, previous studies on Staph.aureus proved that enterotoxin PCR determinations are in a high agreement (97-100\%) with the toxin production as defined by immunoassays (Letertre et al., 2003). Pinto et al. (2005) found a total of $40(30 \%)$ Staph.aureus food isolates positive for se genes. Among them, the sec genotype was the most frequent (22 strains, $20 \%$ of total se positive strains) and sea the second more frequent (14 strains, 13\%), which is in accordance with the results obtained by (Fueyo et al., 2001). Meanwhile Ikeda et al. (2004) did not detect any of Seb, Sec, Sed genes in any of the skim milk samples but could detect Sea and Seh in 10 samples and Seg and Sei genes were detect in 7 samples.

\section{CONCLUSION}

The microbiological examination of the present study revealed that high incidence of different kinds of pathogenic microorganisms that collectively constitutes public health hazard to consumers as Salmonellae, E.coli and Staph.aureus which are a true indicator of poor sanitary condition, cross contamination, fecal pollution, and bad personal hygiene conditions during handling, packing and selling. So, new strategies such as control of raw materials, proper handling, cleaning and disinfection of equipment from farm to fork must be adopted. Also, using of multiplex PCR technique for detection of Staph.aureus enterotoxins based on genotypic basis allowed rapid, reliable, effeicient and less costly compared with routine laboratory diagnosis. It could be implemented as an alternative to phynotype and immunology- based tests in the routine food microbiological analysis.

\section{REFERENCE}

AbdEl-Aziz, A.T.N.; Hassan, M.K.; Shabaan, A.I. and Elmonm, K.M.A. (2001): Prevalence of Salmonella and Listeria in Cairo-poultry abattoir and broiler carcasses. J. Egypt. Vet. Med. Ass., 61(60): 209-218.

Akbar, A. and Anal, K.A. (2011): Food safety concerns and food- borne pathogens, Salmonella, Escherichia coli and Campylobacter. FUUAST journal of Biology, 1(1):5-17.

Amin, H. (2008): Characterization of certain bacteria isolated from deboned poultry meat. Ph.D. Thesis, Fac. Vet. Med., Alex. Univ., Egypt.

Amin, H. and Abd El-Rahman, A. (2015): Molecular Characterization of Salmonella Enterica isolated from chicken meat and its products by Multiplex PCR. Alexandria J. of Vet. Sci., 46:155-160.

Anon (1996): Principles and Guidelines for the Application of Microbiological Risk Assessment. CX/FH 96/10. Twenty-ninth Session of the Codex Committee on Food Hygiene. Washington, 21-25.FAO, Rome.

Baird, D. (1996): Staphylococcus: cluster forming Gram-positive cocci. In: Collee JG, Fraser AG, Marmion BP, Simmons A, editors. Mackie and McCartney practical medical microbiology. 14thed. NewYork: Churchhill Livingstone; 1996. p. p247 
Bhattacharjee, P.S.; Kundu, R.L.; Biswas, R.K.; Mazumder, J.U.; Hossain, E. and Miah, A.H. (1996): A retrospective analysis of chicken diseases diagnosed at the central disease investigation laboratory, Dhaka, Bangladesh. Bangladesh Veterinary Journal, 30: 105-113.

Bergdoll, M.S. (1989): Staphylococcus aureus. Foodborne Bacterial Pathogens (Doyle MP, ed), pp. 463-523. Marcel Dekker Inc., New York, Basel.

Carraminana, J.J.; Yanguela, J.; Blanco, D.; Rota, C.; Agustin, A.I.; Arino, A. and Herrera, A. (1997): Salmonella incidence and distribution of serotypes throughout processing in a Spanish poultry slaughterhouse. J. Food Prot., 60(11): 1312-1317.

Chang, Y.H. (2000): Prevalence of Salmonella spp. in poultry broilers and shell eggs in Korea. J. Food Prot., 63(5): 655-658.

Coburn, B.; Grassl, G.A. and Finlay, B.B. (2007): Salmonella, the host and disease: a brief review. Immunol. cell boil., 85 (2): 112-118.

Cruickshank, R.; Duguid, J.P.; Marmion, B.P. and Swain, R.H. (1975): Medical Microbiology. $12^{\text {th }}$ ed. Vol. II. Livingstone. Limited, Edinburg, London and New York.

Echeverria, P.; Taylor, D.N.; Serwatana, J.; Leksomboon, Y.; Chaicumpa, W.; Tirapat, C.C. and Rowe, B. (1987): Potential sources of enteropathogenic $E$. coli in homes of children with diarrhea in Thailand. WHO, 65(2): 207215.

Eley, A.R. (1992): Microbial food poisoning. $1^{\text {st }}$ Ed. Charman, Hall, London, Glasgow and New York.

Feng, P.; Weagant, S.D. and Grant M.A. (2002): Enumeration of Escherichia coli and the coliform bacteria. In Merker R.I. (Eds). Bacteriological analytical manual, $8^{\text {th }}$ ed. revision A. U.S. Food and Drug Administration, College Park, MD.

Frazier, W.C. and Westhoff, D.C. (1983): Food microbiology. $3^{\text {rd }}$ Ed., Tata McGraw Hill Publ. Co., New Delhi.

Fueyo, J.M.; Martin, M.C.; Gonzalez-Hevia, M.A. and Mendoza, M.C. (2001): Enterotoxin production and DNA fingerprinting in Staphylococcus aureus isolated from human and food samples. Relations between genetic types and enterotoxins. Int. J. Food Microbiol., 67, 139-145.

Geillhausen, B.; Schiitt Gerowitt, H.; Aleksic, S.; Koenen, R; Mauff, G. and Pulverer, G. (1996): Compylobacter and Salmonella contamination fresh chicken meat. Zentrabl. Bakteriol., 284(2-3): 241-245.

Hashim, E.S.Y. (2003): Aerobic and anaerobic enterotoxigenic bacteria in ready-to-eat food. Ph.D. Thesis, Fac. Vet. Med. Moshtohor, Zagazig Univ. Benha Branch.
Hennekinne, JA.; Buyser, ML. and Dragacci, S. (2012): Staphylococcus aureus and its food poisoning toxins: Characterization and outbreak investigation., 23 avenue du General deGaulle, 94706 Maisons-Alfort, France.

Holt, J.G.; Kreig, N.R.; Sneath, P.H.; Staley, J.T. and Williams, S.T. (1994): Bergey's manual of determinative bacteriology. 9th ed. BaLtimore, MD: WiLLiamsan WiLkins, p. 151-157.

Hosam, A.A. (2005): Enteropathogens in poultry meat and some poultry products. Ph.D. Thesis, Meat hygiene, Fac. Vet. Med. Alex. Univ.

Hossam, S.A. (2012): Bacteriological and viral view of poultry meat prepared in private poultry shops. M.V.Sc. (Meat Hygiene), Fac. Vet. Med., Alex Univ.

Hossain, M.T.; Siddique, M.P.; Hossain, F.M.A.; Zinnah, M.A.; Hossain, M.M.; Alam, M.K.; Rahman, M.T. and Choudhury, K.A. (2008): Isolation, identification, toxin profile and antibiogram of Escherichia coli isolated from broilers and layers in Mymensingh district of Bangladesh. Bangladesh Journal of Veterinary Medicines 6 (1): 01-05.

Ikeda, T.; Tamate, N.; Yamaguchi, K. and Makino, S. (2004): Mass outbreak of food poisoning disease caused by small amounts of Staphylococcal Enterotoxins A and H. Applied and Environmental Microbiology, p. 27932795

ISO, 6579 International Organization for Standardization (2002): Microbiology of food and animal feeding stuffs -Horizontal method for the detection of gene in isolated Salmonella from Broilers by PCR Method. Int. J. Poultry. Sci. 4(5): 557-559.

Jamshidi, A.; Bassami, M.R. and Afshari-Nic, S. (2009): Identification of Salmonella spp. and Salmonella typhimurium by a multiplex PCRbased assay from poultry carcasses in Mashhad-Iran. Int. J. Vet. Res., 3(1): 43-48.

Kauffman, G. (1974): Kauffmann white scheme. J. Acta. Path. Microbiol. Sci., 61:385.

Kimura, A.C.; Reddy, V. and Marcus, R. (2004): Chicken consumption is a newly identified risk factor for sporadic Salmonellae enteric serotype enteritidis infections in the United State. Clin. Infect. Dis, 38: 244-252.

Klotz, M.; Opper, S.; Heeg, K. and Zimmermann, S. (2003): Detection of Staphylococcus aureus Enterotoxins A to D by Real-Time Fluorescence PCR Assay Journal of clinical microbiology, 41 (10): 4683-4687.

Kok, T.; Worswich, D. and Gowans, E. (1996): Some serological techniques for microbial and viral infections. In Practical Medical Microbiology (Collee, J.; Fraser, A; Marmion, B. and Simmons, A., eds.), $14^{\text {th }}$ ed., Edinburgh, Churchill, Linvingstone, UK. 
Kozacinski, L.; Hadziosmanovic, M. and Zdolex, N. (2006): Microbiological quality of poultry meat on the Croatian market. Veterinarski Ashiv, 76(4): 305-313.

Lachica, R.V.F.; Genigeorgis, C. and Hoeprich, P.D. (1971): Meta chramaticagar-diffusion methods for detecting staphylococcal nuclease activity. J. Appl. Microbiol., 88:1503.

Letellier, A.; Messier, S. and Quessy, S. (1999): Prevalence of Salmonella species and Yersinia enterocolitica in finishing swine at Canadian abattoir. J. Food Prot. 62(1): 22-25.

Letertre, C.; Perelle, S.; Dilasser, F. and Fach, P. (2003): Identification of a new putative enterotoxin SEU encoded by the egc cluster of Staphylococcus aureus. J. Appl. Microbiol., 95:38-43.

Li, Y.; Zhuang, S. and Mstapha, A. (2005): Application of amultiplex PCR for the simultaneous detection of Escherichia coli O157:H7, Salmonella and Shigella in raw and ready-to-eat meat products. J. Meat Sci., 71: 402-406.

Mehrotra, M.; Wang, G. and Johnson, W. (2000): Multiplex PCR for detection of genes for Staphylococcus aureus enterotoxins, exfoliative toxins, toxic++ shock syndrome toxin 1, and methicillin resistance. J. Clin. Microbiol., 38: 1032-1035.

Mohammed, O.H. (2012): Isolation of some enteropathogenesis from retailed poultry meat in Alex. Province. Ph.D. (meat Hygiene), Fac. Vet. Med., Alex. Univ.

Mohammed, I.A. (2013): Microbiological comparison between broiler chickens produced in poultry abattoir and private shops, Ph.D. (Meat Hygiene). Fac. Vet. Med., Alex. Univ.

Momtaz, H.; Dehkordi, F.S.; Rahimi, E.; Asgarifar, A. and Momeni, M. (2013): Virulence genes and antimicrobial resistance profiles of Staphylococcus aureus isolated from chicken meat in Isfahan province, Iran. Islamic Azad University, PO Box 166, Shahre Kord, Iran.

Moury, F.; Brisabois, A. and Fremy, S. (1998): Surveillance program of Salmonella strains in food hygiene: data from GENEVA, Paris. The $4^{\text {th }}$ World Congress, Foodborne Infections and Intoxication. II: 784-787, 7-12 June, Berlin, Germany.

Mulder, R.W.A.W. and Schlundt, J. (1999): Safety of poultry meat: from farm to table. In: International Consultative Group on Food Irradiation (ICGFI), from their FAO/IAEA/WHO

National Academy of Sciences (1985): An evaluation of the role of microbiological criteria for foods and food ingredients. National Academy Press, Washington DC.
Nawar, E.M. and Khedr, A.M. (2014): Molecular studies on Salmonella species isolated from chicken. Alex. J. Vet. Sci. 43 (1):58-64.

Pinto, B; Chenoll, E. and Aznar, R. (2005): Identification and typing of food borne Staphylococcus aureus by PCR-based techniques. Syst. Appl. microbial. 37: 40124019.

Rabie, N.; Khalifa, N.; El Radwan, M. and Afify, J. (2012): Epidemiological and molecular studies of Salmonella isolates from chicken, chicken meat and human in Toukh, Egypt. Global Vet., 8 (2): 128-132.

Salehi, T.Z.; Mahzounieh, M. and Saeedzadeh, A. (2005): Detection of Inv A Salmonella from briolers by PCR. International journal of poultry science, 4(8): 557-559.

Shah, D.; Shringi, S.; Besser, T. and Call, D. (2009): Molecular detection of foodborne pathogens, Boca Raton: CRC Press, In Liu, D. (Ed). Taylor \& Francis group, Florida, USA, Pp. 369-389.

Shar, A.H.; Kazi, Y.F.; Kanhar, N.A.; Soomro, I.H.; Zia, S.M. and Ghumro, P.B. (2010): Drinking water quality in Rohri City, Sindh, Pakistan. African Journal of Biotechnology 9 (42): 71027107

Sidhu, M.S.; Oppegaard, H.; Devor, T.P. and Sorum, H. (2007): Persistance of multidrug-resistant Staphylococcus Heamolyticus in an animal veterinary teaching hospital clinic. Microb. Drug Resist. 13: 271-280.

Suthienkul, O.; Brown, J.E.; Seriwatana, J.; Tienthongdee, S.; Sastravaha, S. and Echeverria, P. (1990): Shiga-Like-ToxinProducing Escherichia coli in retail meat and cattle in Thailand. Applied and Environmental Microbiology 56 (4): 1135-1139.

Tamarapu, S.; McKillip, J.L. and Drake, M. (2001): Development of a Multiplex Polymerase Chain Reaction assay for detection and differentiation of Staphylococcus aureus in dairy products. J. Food Prot., 64: 664-668.

Tibaijuka, B.; Molla, B.; Hildebrandt, G. and Kleer, J. (2003): Occurrence of Salmonella in retail raw chicken products in Ethiopia. Berl. Munch Tierarztl Wochenschr, 116(1-2): 55-58.

Uyttendaele, M.R.; Debevere, J.M.; Lips, R.M. and Neyts. K.D. (1998): Prevalence of Salmonella in poultry carcasses and their products in Belgium. Int. J. Food. Microbiol., 40(2): 1-8.

Vaidya, V.M.; Paturka, A.M.; Waskar, V.S.; Zende, R.J. and Rawool, D.B. (2005): Detection of indicator organisms on poultry carcass sites in an organized slaughterhouse. J. of Muscle Foods, 16(4): 289-297.

Wales, A.D. and Davies, R.H. (2011): A critical review of Salmonella typhimurium infection in laying hens. Avian Pathol., 40 (5): 429-436. 
Ward, D.; Bernard, D.; Collette, R.; Kramer, D.; Hart, K.; Price, R. and Otwell, S. (1997): Hazards found in sea foods. Appendix III. In Hazards analysis and critical control point, training curriculum, $2^{\text {nd }}$ Ed. 173-188 UNC-SG96-62. North Carolina Sea Grant, Raleigh, NC.

Wehab, H.H. and Aideia, H.A.M. (2002): Chemical and bacteriological studies on different types of luncheon. J. Egypt. Vet. Med. Ass., 62(6): 103-112.

Whyte, P.; McGill, K.; Collins, J. and Gormley, E. (2002): The prevalence and PCR detection of Salmonella contamination in raw poultry. Vet. Microbiol., 2; 89(1): 53.

WHO/ FAO (World Health Organization, Food and Agriculture Organization of the United Nations) (2002): Risk assessments of Salmonella in eggs and chicken broilers. Series no. 2, Geneva: P. 328. Available from: http://www. fao.org/DOCREP/005/Y4392E/ $\mathrm{y} 4392 \mathrm{e} 00$

Zhao, C.; Ge, B.; Devillena, J.; Sudler, R.; Yeh, E.; Zhao, S.; White, D.G.; Wagner, D. and Meng, J. (2001): Prevalence of Campylobacter spp., Escherichia coli and Salmonella serovars in retail chicken, turkey, pork and beef from the Greater Washington DC, area. App. Environ. Microbiol., 67(12): 5431-5436.

Zhao, S.; McDermott, P.F.; Friedman, S.; Abbott, J.; Ayers, S.; Glenn, A.; Hall-Robinson, E.; Hubert, S.K.; Harbottle, H.; Walker, R.D.; Chiller, T.M. and White, D.G. (2006): Antimicrobial resistance and genetic relatedness among Salmonella from retail food of animal origin: NARMS retail meat surveillance. Food Borne Pathog. Dis., 3(1): 106-117.

\section{الكثف عن بعض البكتريا الممرضة فى لحوم الاجاج المباعة في محلاث الاواجن \\ شيرين عبل الفتاح بيس ، غادة احد الجمال \\ Email: shereen_color@yahoo.com Assiut University web-site: www.aun.edu.eg}

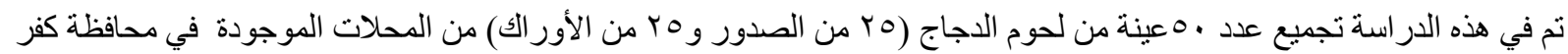

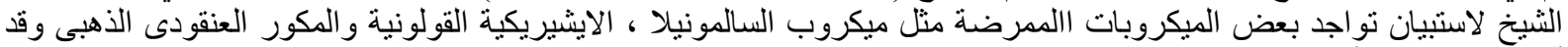

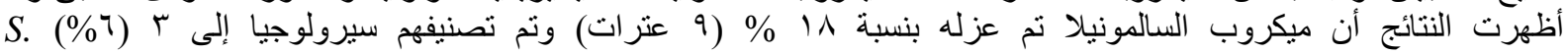

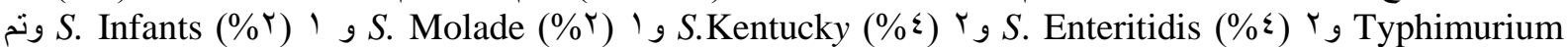

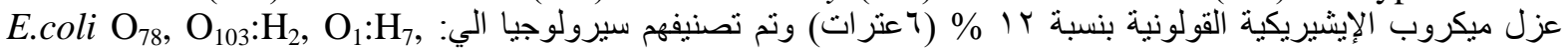
هيناب

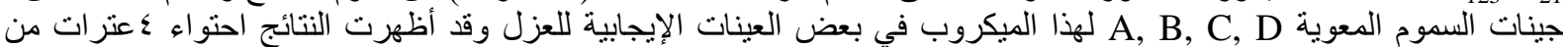

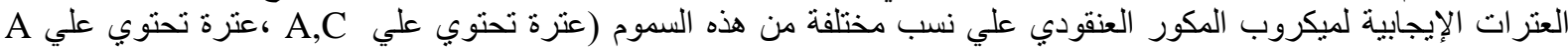

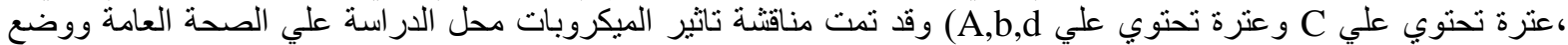
التوصيات اللازمة للحد من إنتشار هذه الميكروبات و والحصول علي منتج صحي آمن للمستهلك. 